Grażyna Bączek, MD, PhD, https:/ / orcid.org/0000-0001-7897-9499

Department of Obstetrics and Gynecology Didactics, Medical University of Warsaw

Monika Szyszka, MSc, https:/ / orcid.org/0000-0002-7494-3111

Żelazna Medical Center, Warsaw

Sylwia Rychlewicz, MSc, https:/ / orcid.org/0000-0002-0392-6074

Żelazna Medical Center, Warsaw

\title{
Multiple children in the context of an analysis of the quality of life, satisfaction and further procreative plans of women - cross-sectional study
}

\author{
Wielodzietność w kontekście oceny jakości życia, satysfakcji i dalszych planów \\ prokreacyjnych kobiet - badanie przekrojowe ${ }^{1}$ \\ https:/ / doi.org/10.34766/fetr.v47i3.929
}

\begin{abstract}
The definition of motherhood is manifold. The responsibilities of motherhood should be considered biologically, psychologically and socially. Conscious motherhood is characterized amongst others by the responsibility of parents for procreative decisions, care for the health, development and safety of the child. In Poland, the model of a woman as mother, who dedicates her life to birthing and raising her offspring, dominates. This has a huge impact on the future functioning of the offspring as citizens of Poland. Materials and method: Study was conducted through a diagnostic survey in a group of 365 women (284 of which are mothers of three or more children, the remaining 81 being mothers of one child). A self-developed survey containing 29 multiple choice questions with a single correct response as well as a standardized assessment tool SWLS- Life Satisfaction Scale E. Diener, R.A. Emmons, R.J. Larson, S. Griffin (adaptation: Z. Juczyński) were used as a research tool. Results: The vast majority of respondents are satisfied with their role as mother $(97.1 \%)$. Many of the women do not plan to have more children $(44.1 \%)$. In the respondents' opinion, childbirth is a social privilege of a woman $(p<0.05)$. Mothers of more than one child have definitively declared that having multiple children does not decrease the quality of life of women, is a source of life satisfaction, aids in the fulfillment of societal roles and does not impede professional development $(p<0.05)$. A constant partner, religious beliefs and relations with other women having more than two children are important factors for respondents when deciding to expand their family $(\mathrm{p}<0.05)$. Women who have given birth to three or more children have greater life satisfaction as compared to mothers of a single child $(\mathrm{p}<0.05)$. Conclusion: Women are happy to be mothers. Motherhood is not a factor hindering their social and private functioning. Women's procreative decisions are influenced by fixed income, formal relationships and religious beliefs. Mothers of large families have greater life satisfaction in comparison to mothers of one child who do not desire more children.
\end{abstract}

Keywords: quality of life, motherhood, multiple children

Abstrakt: Macierzyństwo jest pojęciem wielowymiarowym. Funkcje macierzyństwa należy rozważać w aspekcie biologicznym, psychologicznym i społecznym. Świadome macierzyństwo cechuje się m.in. odpowiedzialnością za decyzje prokreacyjne, troską o zdrowie, rozwój i bezpieczeństwo dziecka. W Polsce dominuje model kobiety - matki, która zmienia dotychczasowy sposób życia, aby oddać się

\footnotetext{
${ }^{1}$ Polska wersja: https:/ / stowarzyszeniefidesetratio.pl/Presentations0/2021-3-Bacz.pdf
} 
rodzeniu i wychowywaniu dzieci. Ma to wpływ na przyszłe funkcjonowanie dzieci oraz na budowaniu $\mathrm{w}$ nich postawy odpowiedzialnych obywateli państwa polskiego. Materiat $i$ metody: Badania metodą sondażu diagnostycznego przeprowadzono w grupie 365 kobiet (284 to matki trojga lub więcej dzieci, pozostałe 81 to matki jednego dziecka). Narzędziem badawczym była autorska ankieta składającą się z 29 pytań zamkniętych jednokrotnego wyboru oraz standaryzowane narzędzie SWLS - skala satysfakcji z życia E. Diener, R.A. Emmons, R.J. Larson, S. Griffin (adaptacja: Z. Juczyński). Wyniki: Zdecydowana większość respondentek jest zadowolona z bycia matką (97,1\%). Duża część kobiet nie planuje mieć więcej dzieci $(44,1 \%)$. W opinii respondentek wielodzietnych poród jest przywilejem społecznym kobiety $(\mathrm{p}<0,05)$. Matki wielodzietne istotnie częściej deklarują, że posiadanie wielu dzieci nie pogarsza jakości życia kobiet, daje satysfakcję życiową, ułatwia pełnienie ról społecznych i nie zamyka drogi do rozwoju zawodowego $(p<0,05)$. Dla respondentek wielodzietnych ważnymi czynnikami mającymi wpływ na podjęcie decyzji o kolejnym potomstwie są: stały partner, przekonania religijne i znajomość osób posiadających więcej niż dwoje dzieci $(p<0,05)$. Kobiety, które rodziły troje dzieci i powyżej mają większą satysfakcję z życia w porównaniu do matek jednodzietnych $(\mathrm{p}<0,05)$. Wnioski: Kobiety są zadowolone $\mathrm{z}$ pełnienia roli matki. Macierzyństwo nie jest dla nich czynnikiem stanowiącym przeszkodę $\mathrm{w}$ funkcjonowaniu społecznym jak i prywatnym. Na decyzje prokreacyjne kobiet wpływają stałe dochody, związek formalny i wyznania religijne. Matki rodzin wielodzietnych mają większą satysfakcję z życia $\mathrm{w}$ porównaniu do kobiet mających jedno dziecko i nie chcących już więcej dzieci.

Słowa kluczowe: jakość życia, macierzyństwo, wielodzietność

\section{Introduction}

The history of humanity has influenced the shaping of motherhood. In many nations' cultural heritage, motherhood is the supreme embodiment of the feminine (Vasyagina, Kalimullin, 2015). The way motherhood is valued in every society influences how women view themselves and how others react to them (Redshaw, Martin, 2011). In the contemporary world, social, political, and economic transformations have improved women's educational and professional status, increasing their role in all public spheres. That has consequently contributed to motherhood ceasing to be the leading value for women (Vasyagina, Kalimullin, 2015).

In Poland, the model of a woman-mother is passed down from generation to generation, which makes Poles have a large number of children when compared to other European nations. In most traditional concepts, motherhood is a natural role for a woman. She should be focused on procreative function and care for her partners. However, we can, still more frequently, notice the modern model of motherhood, which relies on the equal distribution of roles between the mother and the father(Dzwonkowska-Godula, 2015).

In the social understanding in Poland, motherhood is a vocation and a moral duty of every woman. It also fulfils a biological function. She is the one who can pass on life and bring it into the world. Starting the hardship of upbringing, she gives up herself and limits the chance for developing her career, all to satisfy her children's needs (McQuaid, Munro, Dabir - Alai, 2012). A married couple who take on the role of parents creates a family that gives its members a sense of security, warmth and care (Lachowska, Matuszewska, Lachowski, 2017). 
Conscious motherhood means that a woman, together with her partner, control their fertility responsibly and decide to have as many children as their material situation will allow when they reach mental, emotional and social maturity in a period physiologically optimal for them. The mother's role is to care for the health, safety and development of the child. From the very first days of life, it is the mother who takes care of the child's hygiene, feeds it and satisfies all its needs(Herbst-Debby, 2018).

Positive motherhood relies on close emotional contact with the child, satisfaction of mental needs, taking care of the child's physical well-being and introducing it to everyday life and social relations (Tataj-Puzyna, Bączek, Baranowska, Doroszewska, 2017).

There are three functions of motherhood: biological, psychological and social. The biological function of motherhood refers to ensuring the continuity of society, striving for a simple replacement of generations. A woman who decides to have children provides the state with future employees, payers, consumers, and responsible citizens. The psychological function of motherhood is based on bringing the child to emotional maturity on various levels. Reasonable use of the principles of raising children allows shaping in them a specific pattern of behaviour and reactions in various situations, which will affect the development of their personalities. Finally, the social function of motherhood is to bring up a person capable of living in the community where they find themselves. The mother implements the rules of the community into the child's life from an early age. Thus, she educates a responsible citizen who will care for the population's welfare and development while complying with its rights and obligations (Bartkowiak, 2015).

The research was conducted to assess the quality of life of women with many children. The dominant factor influencing their perception of life is motherhood. A woman contributes to the proper functioning of the world by giving a part of herself. By creating the right conditions for growth, she provides children with good health, emotional and social development. Therefore, assessing various aspects of motherhood and studying the quality of life of mothers with many children can contribute to the development of social and health programmes supporting women in their mothering function.

\section{Research objective}

The study aimed at analysing the quality of life, satisfaction and further reproductive plans of women depending on the number of children they have.

\subsection{Material and methods}

The survey was carried out in a group of 365 women. The study group consisted of 284 women - mothers of three or more children, 81 respondents, mothers of one child, were 
included in the control group). The research tool was an original questionnaire consisting of 29 closed-ended single-choice questions and a standardised SWLS tool - the satisfaction with life scale by E. Diener, RA Emmons, RJ Larson, and S. Griffin (adapted by Z. Juczyński). The questionnaire consists of five statements with which the surveyee was to agree or not by choosing one of the seven possible answers.

The questions included in the proprietary survey concerned the woman's satisfaction with being a mother, further procreation plans and the reasons behind the decision to have or not have any more children. The questions also concerned the control and assessment of health condition in its various aspects based on the WHO definition, health is a state of complete physical, mental and social well-being "(World Health Organization, 2014).

\subsection{Characteristics of the study and control group}

Three hundred sixty-five women participated in the study. The study group consisted of 284 mothers of various origins and education, with three or more children living in cities and villages, living with a partner, or single mothers. The control group included 81 mothers with one child and planning no more children with a similar demographic status. A majority of the group were married women (95.8\% - with many children; $69.1 \%$ - with one child). In terms of residence, the largest group are mothers living in cities with more than 500,000 inhabitants (38.7\% - with many children; 38.3\% - with one child). Most respondents have higher education (77.1\% - with many children; $63 \%$ - with one child). Employment is declared by $57.4 \%$ of women with many children and $67.9 \%$ of women with one child. $67.6 \%$ of the surveyed mothers with many children reported employment in line with the learned profession, and $59.3 \%$ of those with one child. The vast majority of women are Catholics (97.1\% - with many children, $80.8 \%$ - with one child) (Tab. 1$)$.

Table No. 1a. Characteristics of the study and control group

\begin{tabular}{|l|l|c|c|}
\hline \multirow{4}{*}{ Marital status } & & one-child & many children \\
\cline { 2 - 4 } & single & $8.6 \%$ & $0.4 \%$ \\
\cline { 2 - 4 } & married & $69.1 \%$ & $95.8 \%$ \\
\cline { 2 - 4 } & divorced & $2.5 \%$ & $1.1 \%$ \\
\cline { 2 - 4 } & widow & $0.0 \%$ & $0.4 \%$ \\
\cline { 2 - 4 } & in a partnership & $19.8 \%$ & $2.5 \%$ \\
\hline Place of residence & village & $9.9 \%$ & $22.9 \%$ \\
\cline { 2 - 4 } & town up to 50,000 & $14.8 \%$ & $8.8 \%$ \\
\cline { 2 - 4 } & city from 50,000 up to 150,000 & $22.2 \%$ & $14.8 \%$ \\
\cline { 2 - 4 } & city from 150,000 up to 500 & $14.8 \%$ & $38.3 \%$ \\
\cline { 2 - 4 } & city over 500,000 & $38.7 \%$ \\
\hline
\end{tabular}


Table No. 1b. Characteristics of the study and control group

\begin{tabular}{|c|c|c|c|}
\hline & & $\begin{array}{l}\text { one- } \\
\text { child }\end{array}$ & $\begin{array}{l}\text { many } \\
\text { children }\end{array}$ \\
\hline \multirow[t]{5}{*}{ Education } & Primary & $0.0 \%$ & $0.7 \%$ \\
\hline & medium school & $0.0 \%$ & $0.7 \%$ \\
\hline & Vocational & $4.9 \%$ & $1.8 \%$ \\
\hline & Secondary & $32.1 \%$ & $19.7 \%$ \\
\hline & Higher & $63.0 \%$ & $77.1 \%$ \\
\hline \multirow[t]{4}{*}{ Religion } & Catholics & $80.8 \%$ & $97.1 \%$ \\
\hline & Atheists & $17.8 \%$ & $0.7 \%$ \\
\hline & Jehovah's witnesses & $1.4 \%$ & $0.4 \%$ \\
\hline & Muslim & $0.0 \%$ & $0.4 \%$ \\
\hline \multirow[t]{2}{*}{ Currently employed } & No & $32.1 \%$ & $42.6 \%$ \\
\hline & Yes & $67.9 \%$ & $57.4 \%$ \\
\hline \multirow[t]{2}{*}{$\begin{array}{l}\text { Employment in accordance with } \\
\text { the profession }\end{array}$} & $\begin{array}{l}\text { Employment different from the } \\
\text { learned profession }\end{array}$ & $40.7 \%$ & $32.4 \%$ \\
\hline & $\begin{array}{l}\text { Employment per the learned } \\
\text { profession }\end{array}$ & $59.3 \%$ & $67.6 \%$ \\
\hline
\end{tabular}

The group structure regarding the number of possessed children shows that the highest percentage (33\%) are mothers of three children. The second-largest group of mothers was that with one child $(22 \%)$. The fertility rate of the surveyed women is presented in detail in Chart 1.

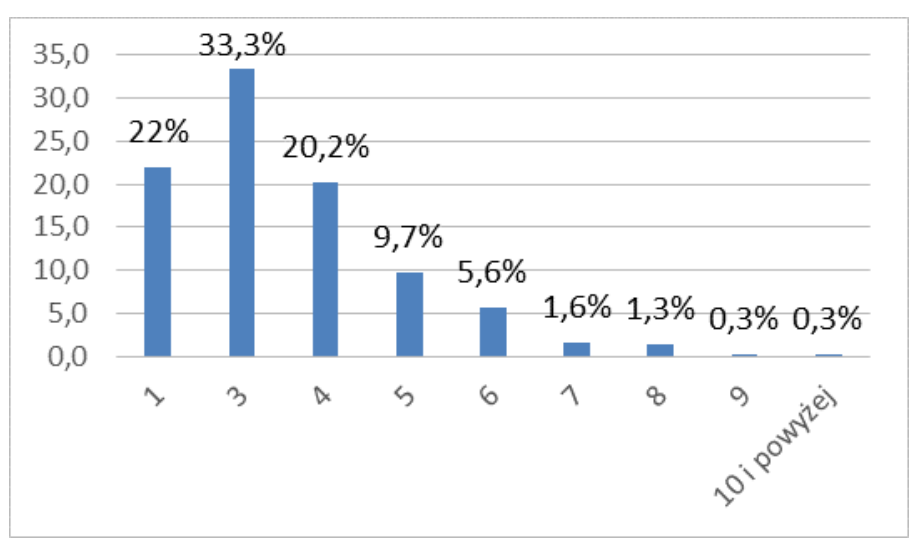

Chart No. 1. Fertility of the study group $(n=365)$

\section{Results}


The first of the studied issues was the degree of satisfaction with being a mother. As many as $78.8 \%$ of the respondents stated that they were definitely satisfied with fulfilling the role of a mother. Another $18.3 \%$ of women were rather satisfied with that. Mothers who were rather not satisfied with being mothers constituted $1.1 \%$ of the respondents, while $0.8 \%$ were definitely dissatisfied. A small percentage of women $(1.1 \%)$ did not have an opinion on the subject.

Due to the high percentage of women who declared satisfaction with being a mother, they were asked about plans for having more children. A negative answer was given by $44.1 \%$ of the respondents. $28.2 \%$ of women planned to have more children, while $27.7 \%$ did not have fully defined procreation plans.

One of the surveyed issues was the respondents' opinions and experiences about motherhood and having many children. Some of them turned out to be statistically significant $(\mathrm{p}<0.05)$. And so, women with many children know significantly more families with many children than mothers with one child. According to the respondents with many children, knowing a family with many children, being brought up in a family with three or more children, formal relationship, and religion have a more significant impact on deciding on having another child, compared to single-child women. In the opinion of mothers with many children, childbirth is a woman's social privilege and having many children gives satisfaction to life and helps fulfil social roles.

Single-child women significantly more frequently agreed with the statements that giving birth to many children deteriorates the woman's health and quality of life and closes the way to career development.

Table No. 2. Women's opinions on motherhood

\begin{tabular}{|c|c|c|c|c|c|c|c|}
\hline & Test group & $\begin{array}{l}\text { Number } \\
\text { of } \\
\text { responde } \\
\text { nts }\end{array}$ & Mean & $\begin{array}{c}\text { Standar } \\
\mathrm{d} \\
\text { deviatio } \\
\mathrm{n}\end{array}$ & $\mathrm{df}$ & $\mathrm{F}$ & $\mathrm{p}$ \\
\hline \multirow{3}{*}{$\begin{array}{c}\text { having a } \\
\text { multiple- } \\
\text { children family } \\
\text { among close } \\
\text { friends }\end{array}$} & $\begin{array}{l}\text { With one- } \\
\text { child }\end{array}$ & 81 & 1.7719 & 0.42 & 1 & \multirow{3}{*}{12.04} & \multirow{3}{*}{$<0.05$} \\
\hline & $\begin{array}{l}\text { With many } \\
\text { children }\end{array}$ & 284 & 1.9225 & 0.27 & 339 & & \\
\hline & Total & 365 & 1.8974 & 0.30 & 340 & & \\
\hline
\end{tabular}




\begin{tabular}{|c|c|c|c|c|c|c|c|}
\hline \multirow{3}{*}{$\begin{array}{c}\text { knowing a } \\
\text { many-children } \\
\text { family/growing } \\
\text { up in a large } \\
\text { family versus } \\
\text { the decision on } \\
\text { having another } \\
\text { child }\end{array}$} & $\begin{array}{l}\text { With one- } \\
\text { child }\end{array}$ & 81 & 1.4359 & 0.55 & 1 & \multirow[b]{3}{*}{22.67} & \multirow[b]{3}{*}{$<0.05$} \\
\hline & $\begin{array}{l}\text { With many } \\
\text { children }\end{array}$ & 284 & 2.1556 & 0.92 & 307 & & \\
\hline & Total & 365 & 2.0647 & 0.91 & 308 & & \\
\hline \multirow{3}{*}{$\begin{array}{l}\text { formal } \\
\text { relationship and } \\
\text { the decision to } \\
\text { have another } \\
\text { child }\end{array}$} & $\begin{array}{l}\text { With one- } \\
\text { child }\end{array}$ & 81 & 2.6667 & 1.52 & 1 & \multirow{3}{*}{173.14} & \multirow{3}{*}{$<0.05$} \\
\hline & $\begin{array}{l}\text { With many } \\
\text { children }\end{array}$ & 284 & 4.5986 & 0.88 & 339 & & \\
\hline & Total & 365 & 4.2757 & 1.24 & 340 & & \\
\hline \multirow{3}{*}{$\begin{array}{l}\text { religion and the } \\
\text { decision to have } \\
\text { another child }\end{array}$} & $\begin{array}{l}\text { With one- } \\
\text { child }\end{array}$ & 81 & 1.6316 & 1.19 & 1 & \multirow{3}{*}{109.74} & \multirow{3}{*}{$<0.05$} \\
\hline & $\begin{array}{l}\text { With many } \\
\text { children }\end{array}$ & 284 & 3.8063 & 1.47 & 339 & & \\
\hline & Total & 365 & 3.4428 & 1.64 & 340 & & \\
\hline \multirow{3}{*}{$\begin{array}{l}\text { childbirth is a } \\
\text { social privilege } \\
\text { of a woman }\end{array}$} & $\begin{array}{l}\text { With one- } \\
\text { child }\end{array}$ & 81 & 2.6842 & 1.35 & 1 & \multirow{3}{*}{24.95} & \multirow{3}{*}{$<0.05$} \\
\hline & $\begin{array}{l}\text { With many } \\
\text { children }\end{array}$ & 284 & 3.5915 & 1.23 & 339 & & \\
\hline & Total & 365 & 3.4399 & 1.29 & 340 & & \\
\hline \multirow{3}{*}{$\begin{array}{l}\text { giving birth to } \\
\text { many children } \\
\text { deteriorates } \\
\text { health }\end{array}$} & $\begin{array}{l}\text { With one- } \\
\text { child }\end{array}$ & 81 & 3.5439 & 1.21 & 1 & \multirow{3}{*}{27.19} & \multirow{3}{*}{$<0.05$} \\
\hline & $\begin{array}{l}\text { With many } \\
\text { children }\end{array}$ & 284 & 2.6162 & 1.23 & 339 & & \\
\hline & Total & 365 & 2.7713 & 1.27 & 340 & & \\
\hline \multirow{3}{*}{$\begin{array}{c}\text { having many } \\
\text { children } \\
\text { deteriorates a } \\
\text { woman's quality } \\
\text { of life }\end{array}$} & $\begin{array}{l}\text { With one- } \\
\text { child }\end{array}$ & 81 & 3.7193 & 1.25 & 1 & \multirow{3}{*}{104.48} & \multirow{3}{*}{$<0.05$} \\
\hline & $\begin{array}{l}\text { With many } \\
\text { children }\end{array}$ & 284 & 2.0246 & 1.12 & 339 & & \\
\hline & Total & 365 & 2.3079 & 1.30 & 340 & & \\
\hline \multirow{3}{*}{$\begin{array}{l}\text { having many } \\
\text { children gives } \\
\text { your life } \\
\text { satisfaction }\end{array}$} & $\begin{array}{l}\text { With one- } \\
\text { child }\end{array}$ & 81 & 3.0351 & 1.18 & 1 & \multirow{3}{*}{110.17} & \multirow{3}{*}{$<0.05$} \\
\hline & $\begin{array}{l}\text { With many } \\
\text { children }\end{array}$ & 284 & 4.4648 & 0.88 & 339 & & \\
\hline & Total & 365 & 4.2258 & 1.08 & 340 & & \\
\hline \multirow{3}{*}{$\begin{array}{l}\text { having many } \\
\text { children helps } \\
\text { fulfil social roles }\end{array}$} & $\begin{array}{l}\text { With one- } \\
\text { child }\end{array}$ & 81 & 2.7018 & 0.99 & 1 & \multirow{3}{*}{68.94} & \multirow{3}{*}{$<0.05$} \\
\hline & $\begin{array}{l}\text { With many } \\
\text { children }\end{array}$ & 284 & 3.9155 & 1.00 & 339 & & \\
\hline & Total & 365 & 3.7126 & 1.10 & 340 & & \\
\hline \multirow{3}{*}{$\begin{array}{l}\text { having many } \\
\text { children blocks } \\
\text { the way to a } \\
\text { career } \\
\text { development }\end{array}$} & $\begin{array}{l}\text { With one- } \\
\text { child }\end{array}$ & 81 & 3.5088 & 1.18 & 1 & \multirow{3}{*}{42.74} & \multirow{3}{*}{$<0.05$} \\
\hline & $\begin{array}{l}\text { With many } \\
\text { children }\end{array}$ & 284 & 2.3592 & 1.22 & 339 & & \\
\hline & Total & 365 & 2.5513 & 1.28 & 340 & & \\
\hline
\end{tabular}


Another issue studied was analysing the factors determining the decision to have another child in both multi- and one-child groups.

Among women with multiple children, factors such as a stable partner, religious beliefs and knowing people who have more than two children were indicated significantly more often $($ p.<0.05). For women with one child, statistically significant factors for procreation decisions were: high salary, social assistance, partner's pressure and providing sibling(s) for the child $(\mathrm{p}<0.05)$. It turned out that health had a more significant impact on the decision about the next child in the group of single-child women. Detailed data are presented in Table 3.

Table No. 3. Analysis of factors influencing the decision to have another child between respondents with many children and with one child $(\mathrm{n}=365)$

\begin{tabular}{|c|c|c|c|c|c|c|c|}
\hline Factors & Test group & $\begin{array}{l}\text { Number of } \\
\text { respondents }\end{array}$ & Mean & $\begin{array}{l}\text { Standard } \\
\text { deviation }\end{array}$ & $\mathrm{df}$ & $\mathrm{F}$ & $p$ \\
\hline \multirow[t]{3}{*}{$\begin{array}{l}\text { Permanent } \\
\text { job }\end{array}$} & $\begin{array}{l}\text { With one- } \\
\text { child }\end{array}$ & 81 & 0.3509 & 0.48 & 1 & \multirow{3}{*}{1.78} & \multirow{3}{*}{0.183} \\
\hline & $\begin{array}{l}\text { With many } \\
\text { children }\end{array}$ & 284 & 0.2641 & 0.44 & 339 & & \\
\hline & Total & 365 & 0.2786 & 0.45 & 340 & & \\
\hline \multirow[t]{3}{*}{ High salary } & $\begin{array}{l}\text { With one- } \\
\text { child }\end{array}$ & 81 & 0.2456 & 0.43 & 1 & \multirow{3}{*}{7.30} & \multirow{3}{*}{$<0.05$} \\
\hline & $\begin{array}{l}\text { With many } \\
\text { children }\end{array}$ & 284 & 0.1127 & 0.32 & 339 & & \\
\hline & Total & 365 & 0.1349 & 0.34 & 340 & & \\
\hline \multirow[t]{3}{*}{$\begin{array}{l}\text { Permanent } \\
\text { partner }\end{array}$} & $\begin{array}{l}\text { With one- } \\
\text { child }\end{array}$ & 81 & 0.4035 & 0.49 & 1 & \multirow{3}{*}{9.66} & \multirow{3}{*}{$<0.05$} \\
\hline & $\begin{array}{l}\text { With many } \\
\text { children }\end{array}$ & 284 & 0.6232 & 0.49 & 339 & & \\
\hline & Total & 365 & 0.5865 & 0.49 & 340 & & \\
\hline \multirow[t]{3}{*}{$\begin{array}{l}\text { Family } \\
\text { traditions }\end{array}$} & $\begin{array}{l}\text { With one- } \\
\text { child }\end{array}$ & 81 & 0.1930 & 0.40 & 1 & \multirow{3}{*}{0.03} & \multirow{3}{*}{0.861} \\
\hline & $\begin{array}{l}\text { With many } \\
\text { children }\end{array}$ & 284 & 0.1831 & 0.39 & 339 & & \\
\hline & Total & 365 & 0.1848 & 0.39 & 340 & & \\
\hline \multirow[t]{3}{*}{$\begin{array}{l}\text { Social } \\
\text { assistance }\end{array}$} & $\begin{array}{l}\text { With one- } \\
\text { child }\end{array}$ & 81 & 0.1228 & 0.33 & 1 & \multirow{3}{*}{18.86} & \multirow{3}{*}{$<0.05$} \\
\hline & $\begin{array}{l}\text { With many } \\
\text { children }\end{array}$ & 284 & 0.0141 & 0.12 & 339 & & \\
\hline & Total & 365 & 0.0323 & 0.18 & 340 & & \\
\hline
\end{tabular}




\begin{tabular}{|c|c|c|c|c|c|c|c|}
\hline \multirow[t]{3}{*}{$\begin{array}{l}\text { Religious } \\
\text { beliefs }\end{array}$} & $\begin{array}{l}\text { With one- } \\
\text { child }\end{array}$ & 81 & 0.1930 & 0.40 & 1 & \multirow{3}{*}{15.71} & \multirow{3}{*}{$<0.05$} \\
\hline & $\begin{array}{l}\text { With many } \\
\text { children }\end{array}$ & 284 & 0.4718 & 0.50 & 339 & & \\
\hline & Total & 365 & 0.4252 & 0.50 & 340 & & \\
\hline \multirow{3}{*}{$\begin{array}{l}\text { Friends with } \\
>\text { than two } \\
\text { children }\end{array}$} & $\begin{array}{l}\text { With one- } \\
\text { child }\end{array}$ & 81 & 0.0000 & 0.00 & 1 & \multirow{3}{*}{7.97} & \multirow{3}{*}{$<0.05$} \\
\hline & $\begin{array}{l}\text { With many } \\
\text { children }\end{array}$ & 284 & 0.1232 & 0.33 & 339 & & \\
\hline & Total & 365 & 0.1026 & 0.30 & 340 & & \\
\hline \multirow[t]{3}{*}{$\begin{array}{l}\text { Starting } \\
\text { family }\end{array}$} & $\begin{array}{l}\text { With one- } \\
\text { child }\end{array}$ & 81 & 0.0702 & 0.26 & 1 & \multirow{3}{*}{0.04} & \multirow{3}{*}{0.849} \\
\hline & $\begin{array}{l}\text { With many } \\
\text { children }\end{array}$ & 284 & 0.0634 & 0.24 & 339 & & \\
\hline & Total & 365 & 0.0645 & 0.25 & 340 & & \\
\hline \multirow[t]{3}{*}{$\begin{array}{l}\text { Desire to be a } \\
\text { mother }\end{array}$} & $\begin{array}{l}\text { With one- } \\
\text { child }\end{array}$ & 81 & 0.4912 & 0.50 & 1 & \multirow{3}{*}{0.21} & \multirow{3}{*}{0.646} \\
\hline & $\begin{array}{l}\text { With many } \\
\text { children }\end{array}$ & 284 & 0.5246 & 0.50 & 339 & & \\
\hline & Total & 365 & 0.5191 & 0.50 & 340 & & \\
\hline \multirow[t]{3}{*}{$\begin{array}{l}\text { Partner } \\
\text { pressure }\end{array}$} & $\begin{array}{l}\text { With one- } \\
\text { child }\end{array}$ & 81 & 0.0702 & 0.26 & 1 & \multirow{3}{*}{11.24} & \multirow{3}{*}{$<0.05$} \\
\hline & $\begin{array}{l}\text { With many } \\
\text { children }\end{array}$ & 284 & 0.0070 & 0.08 & 339 & & \\
\hline & Total & 365 & 0.0176 & 0.13 & 340 & & \\
\hline \multirow{3}{*}{$\begin{array}{l}\text { Providing } \\
\text { sibling(s) for } \\
\text { the child }\end{array}$} & $\begin{array}{l}\text { With one- } \\
\text { child }\end{array}$ & 81 & 0.4386 & 0.50 & 1 & \multirow{3}{*}{7.08} & \multirow{3}{*}{$<0.05$} \\
\hline & $\begin{array}{l}\text { With many } \\
\text { children }\end{array}$ & 284 & 0.2641 & 0.44 & 339 & & \\
\hline & Total & 365 & 0.2933 & 0.46 & 340 & & \\
\hline \multirow{3}{*}{$\begin{array}{l}\text { Fulfiling } \\
\text { plans to have } \\
\text { a child of a } \\
\text { specific } \\
\text { gender }\end{array}$} & $\begin{array}{l}\text { With one- } \\
\text { child }\end{array}$ & 81 & 0.0702 & 0.26 & 1 & \multirow{3}{*}{3.16} & \multirow{3}{*}{0.076} \\
\hline & $\begin{array}{l}\text { With many } \\
\text { children }\end{array}$ & 284 & 0.0246 & 0.16 & 339 & & \\
\hline & Total & 365 & 0.0323 & 0.18 & 340 & & \\
\hline \multirow[t]{3}{*}{ Health } & $\begin{array}{l}\text { With one- } \\
\text { child }\end{array}$ & 81 & 0.1228 & 0.33 & 1 & \multirow{3}{*}{3.87} & \multirow{3}{*}{0.050} \\
\hline & $\begin{array}{l}\text { With many } \\
\text { children }\end{array}$ & 284 & 0.0528 & 0.22 & 339 & & \\
\hline & Total & 365 & 0.0645 & 0.25 & 340 & & \\
\hline
\end{tabular}


The studies also assessed satisfaction with life (SWLS) in both groups. The results show that women who gave birth to three or more children enjoy significantly higher satisfaction with life $(\mathrm{p}<0.05)$. Detailed data are presented in Table 4.

Table No. 4. Analysis of the standardised test (SWLS) performed

\begin{tabular}{|c|c|c|c|c|c|c|c|c|}
\hline Factors & Test group & $\begin{array}{c}\text { Number of } \\
\text { respondent } \\
\text { s }\end{array}$ & Mean & $\begin{array}{c}\text { Standard } \\
\text { Deviation }\end{array}$ & & df & F & $p$ \\
\hline \multirow{2}{*}{$\begin{array}{c}\text { Satisfaction } \\
\text { with life }\end{array}$} & $\begin{array}{c}\text { With one- } \\
\text { child }\end{array}$ & 81 & 21.3684 & 5.98 & & 1 & & \\
\cline { 2 - 9 } & $\begin{array}{c}\text { With many } \\
\text { children }\end{array}$ & 284 & 25.3110 & 5.41 & & 338 & 24.30 & $<0.05$ \\
\cline { 2 - 8 } & Total & 365 & 24.6500 & 5.67 & & 339 & \\
\hline
\end{tabular}

\section{Discussion}

Having children is often associated with a change in current functioning, but a woman can also find joy and fulfilment in her daily hardships (Malina, 2011).

As the own research has shown, most women are satisfied with being mothers. The research by Machaj - Szczerek et al. shows that almost half of the respondents $(49.2 \%)$ consider motherhood to be a woman's fulfilment. However, a small percentage of women (1.1\%) believe that being a mother is difficult (Machaj-Szczerek, Stankowska, 2013).

Despite the positive assessment of motherhood presented in the authors' own study, most respondents do not plan to have more children. In a study by Sobotka and Beaujouan, most women aged 35-44 who have no or one child still plan to have more children (Sobotka, Beaujouan, 2018). In research by CBOS, $46 \%$ of respondents with one child will not decide to have another child because their procreation plans have been achieved, and in the case of women with two or more children - 89\% (CBOS, 2013).

In my research, the decision about having more children by mothers with multiple offspring is affected mainly by the following conditions: a steady partner, religious beliefs and knowing people with more than two children. Duszczyk et al. found that social assistance is a factor that influences fertility. Families declaring low income cannot decently ensure their children's well-being and choose not to have offspring (Duszczyk, Fihel, Kiełkowska, Kordasiewicz, Radziwinowiczówna, 2014).

According to the own study respondents, childbirth is a social privilege of a woman and motherhood gives satisfaction with life and helps fulfil social roles. Most respondents disagree with the statement that having many children worsens a woman's health condition and quality of life or closes her path to career development. As Szczerek-Machaj et al. stated in her research, motherhood is a duty $(4.7 \%)$, a calling $(13.7 \%)$, fulfilment $(49.2 \%)$ and the 
sense of a woman's life (29.5\%). She also showed that giving birth to children gives a sense of fulfilment $(28.3 \%)$, is a pleasure, joy (57.4\%) and is an element of a woman's development (66.5\%) (Machaj-Szczerek, Stankowska, 2013). Also, Redshaw and Martin found that being a mother is extremely enjoyable and a source of pride for many women, despite routine childcare activities. They also note that it can be an effort for some women, depending on individual circumstances, material resources, quality of partnerships, and broader social and emotional support (Redshaw, Martin, 2011).

As shown by the results of own research based on the SWLS questionnaire, being a mother of many children is satisfactory for a woman. However, a similar study using the same questionnaire also showed that mothers' satisfaction with life depends on developing a secure partnership style. The stronger the relationship with the partner, the higher the satisfaction with life during motherhood (Malina, 2011).

Młynarska's research has shown that the most critical factor for having children is a permanent job, which guarantees material existence. Also, the age at which a woman becomes pregnant is relatively important. It limits to some extent the reproductive plans and affects the ability to have more children (Młynarska, 2011).

Buber-Ennser et al. found that a higher level of religiosity is associated with the increased importance of motherhood in their lives among both mothers and women without children (Buber-Ennser, Skirbekk, 2016). In the own research, the steady partner, desire for motherhood, and religious belief affect women's decisions about children.

Women with many children may perceive motherhood as a challenge that is not an obstacle to their social and professional development. That translates into their assessment of satisfaction with life. However, the quality of life of women with three or more children depends on many biological, psychological and social factors. They also influence these mothers' desire to have another offspring.

\section{Conclusions}

The conducted research clearly shows that the factors with a significant impact on the further reproductive decisions of women with many children include: being in a formal relationship, the desire to be a mother and religious beliefs. Women with more than three children declare greater satisfaction with life compared to mothers with one child. For women, having many children is not an obstacle to fulfilling their social and professional roles. Disseminating the positive values of motherhood could change how the mother is perceived in today's world and what role she plays in society. The social creation of a favourable image of large families should be based on reliable scientific research showing, above all, the quality and satisfaction with life in this family model. 


\section{Bibliography:}

Bartkowiak, E. (2015). Obraz matki i macierzyństwa w przekazach źródłowych z historii wychowania, Wychowanie w Rodzinie, 2, 271-294.

Buber-Ennser, I., Skirbekk, V. (2016). Researchers, religion and childlessness, Journal of Biosocial Science, 48, 391-405.

Centrum Badania Opinii Społecznej, (2013). Komunikat z badań. Postawy prokreacyjne Polaków, Available at [13/06/2021].

Duszczyk, M., Fihel, A., Kiełkowska, M., Kordasiewicz, A., Radziwinowiczówna, A. (2014). Analiza kontekstualna i przyczynowa zmian rodziny i dzietności, Ośrodek Badań nad Migracjami, Uniwersytet Warszawski, 2, 22-28.

Dzwonkowska-Godula, K. (2015). Tradycyjnie czy nowocześnie? Wzory macierzyństwa i ojcostwa w Polsce, Wydawnictwo Uniwersytetu Łódzkiego.

Herbst-Debby, A. (2018). Doing good motherhood: Creating their own responsible single mother model, Women's Studies International Forum, 69, 151-158.

https://www.cbos.pl/SPISKOM.POL/2013/K_029_13.PDF.

Lachowska, B., Matuszewska, A., Lachowski, S. (2017). System wartości kobiet a ich postawy wobec macierzyństwa, Kwartalnik Naukowy Fides et Ratio, 1 (29), 67-79.

Machaj-Szczerek, A., Stankowska, I. (2013). Przekonania dotyczące macierzyństwa-badania własne, Pielęgniarstwo Polskie, 3 (49), 176-186.

Malina, A. (2011). Styl przywiązania młodych kobiet, a ich satysfakcja z życia w różnych fazach rozwoju rodziny, Psychologia Rozwojowa, 1, 41-55.

McQuaid, R., Munro, A., Dabir-Alai, P. (2012). Motherhood and its impact on career progression, Gender in Management: An International Journal, 27, 346-364.

Młynarska, M. (2011). Kiedy mieć dziecko? Jakościowe badanie procesu odraczania decyzji o rodzicielstwie, Psychologia Społeczna, 3, 226-240.

Redshaw, M., Martin, C. (2011). Motherhood: a natural progression and a major transition, Journal of Reproductive and Infant Psychology, 29, 305-307.

Sobotka, T., Beaujouan, É. (2018). Late Motherhood in Low-Fertility Countries: Reproductive Intentions, Trends and Consequences. Preventing Age Related Fertility loss, Switzerland: Springer International Publishing, 11-29.

Tataj-Puzyna, U., Bączek, G., Baranowska, B., Doroszewska, A. (2017). Doświadczenie macierzyństwa - badania sondażowe matek w Warszawie, Kwartalnik Naukowy Fides et Ratio, 2 (30), 124-144.

Vasyagina, N.N., Kalimullin, A.M. (2015). Retrospective Analysis of Social and Cultural Meanings of Motherhood in Russia, Review of European Studies, 7, 61.

World Health Organization, (2014). Basic documents. Forty - eighth edition, 1. Available at [13/06/2021]: https://apps.who.int/gb/bd/PDF/bd48/basic-documents-48thedition-en.pdf. 